\title{
THE GROWTH OF THE ANTI-JEWISH STEREOTYPE
}

\author{
AN ATTEMPT AT A HYPOTHETICAL-DEDUCTIVE METHOD \\ OF HISTORICAL RESEARCH*
}

\section{Introduction}

There are three good reasons at the present time to try to arrive at an historical model to explain the development of anti-Jewish stereotyping and prejudice, and in this way, provided it is worked out at a sufficiently high level of abstraction, at an historical model of racism.

The first reason is that both the Netherlands and its neighbours are increasingly faced with racism and that for a good line of action it is necessary to collect all kinds of knowledge. Moreover, it is desirable that historians prove willing to co-operate by making their particular contribution to this collection of knowledge. The second reason is that in contemporary thinking about history a tendency seems to have made itself felt that considers the narrative element of history as the only true activity of the historian, so that a hypothetical-deductive, one might say Popperian, ${ }^{1}$ approach to the past seems to be wrong. Although I do not want to enter into a methodological discussion, which I am glad to leave to my friend P. H. H. Vries, who has very capably formulated a point of view that I subscribe to ${ }^{2}$ my intention is to show the usefulness of an abstract, partially mathematical, model in this article. By the way, in the framework of an article it is impossible to present an extensive test of the predictions of the model by means of source material. It can only be hinted at. This article is not non-narrative because I want it to be non-narrative, but because of lack

* This article is a translation and an adaptation of "De Groei van het Anti-Joodse Stereotype. Een poging tot een hypothetisch-deductieve werkwijze in historisch onderzoek", in: Tijdschrift voor Sociale Geschiedenis, X (1984), pp. $34 f f$.

1 See notably K. R. Popper, Conjectures and Refutations. The Growth of Scientific Knowledge, 2nd ed. (London, 1976).

2 P. H. H. Vries, "Geschiedbeoefening, Historisme en Positivisme. Een overzicht van intenties, pretenties en misverstanden in de debatten over de aard van de huidige sociaalwetenschappelijke geschiedbeoefening", in: Theoretische Geschiedenis, XII (1985), pp. $141 \mathrm{ff}$. 
of space. A full exposition would need a book. ${ }^{3}$ I shall only present in summary what $I$ hope is the logical argument that lies at the basis of the model.

The third reason, more especially directed at the question of the origin of anti-Jewish prejudice, lies in the discussion provoked by the book written by Hans Jansen, Christelijke theologie na Auschwitz (Christian theology after Auschwitz). ${ }^{4}$ In this book a practising Christian confesses the historical guilt Christianity has towards the Jews. As such it is a courageous and noble book, excellent in many ways. On the one hand it seems a competent recapitulation of the oldest Contra Judaeos literature and the literature about these documents; on the other hand it is an original contribution to the knowledge of more recent anti-Jewish tendencies in the newer, especially German theology, which is one of the reasons why the German Churches were so accommodating to Hitler. Up to this point there is no ground for discussion, except about details. If, however, Jansen's argument means that theological stigmatizing is an almost sufficient explanation of the phenomenon of anti-Semitism (see, e.g., his remarks about the parallelism of theological stigmatizing and National-Socialist propaganda ${ }^{5}$ ), and it is not quite clear that this is not meant, then there is a good ground for disagreement, because he then makes a necessary into a necessary and sufficient condition, and in this way, strange as it may sound, plays down the problem. Quite apart from the fact whether this imputation to Jansen is correct or not, it may be useful to bring to the fore other than theological aspects.

To begin with a statement of principle. Until the contrary has been proved, it will be assumed here that everywhere, at all times, hatred of Jews has come into being in the same way. It will be clear to the reader that this idea is a complete negation of the idea that, in order to understand historical situations the only true method is to concentrate on unique and specific aspects.

\section{The problem}

When measured by the number and size of anti-Semitic parties, the number and circulation of anti-Semitic propaganda literature, the number and severity of public acts of violence or cases of discrimination against Jews, which can be considered as a practical, if imperfect, yardstick, it becomes

${ }^{3}$ I am preparing a book on the subject, which will be published soon, presumably in 1986.

${ }^{4}$ H. Jansen, Christelijke Theologie na Auschwitz, Vol. I: Theologische en kerkelijke wortels van het antisemitisme, 2nd ed. (The Hague, 1982).

${ }^{5}$ Ibid., pp. 556ff. 
clear that in the nineteenth and twentieth centuries anti-Semitism occurred in Europe

1. in some predominantly Roman Catholic countries (e.g., Poland, France) and not in others (e.g., Italy, Belgium);

2. in some predominantly Orthodox countries (Russia, Rumania) and not in others (Bulgaria, Greece);

3 . in some predominantly Protestant countries (Germany) and not in others (Great Britain, the Netherlands, Scandinavia);

4. in some highly industrialized countries (Germany, Cis-Leithan Austria) and not in others (Britain, the Netherlands, Belgium, Sweden);

5. in some agrarian countries (Poland, Rumania, Hungary) and not in others (Serbia, Bulgaria, Greece, Ireland);

6 . in some countries with $1 \%$ or less Jewish inhabitants (Germany, France) and not in others (Italy, Belgium, Britain);

7. in some countries with more than $1.5 \%$ Jewish inhabitants (Poland, Russia) and not in others (Greece, the Netherlands). ${ }^{6}$

Similar strange contradictions can be found. E.g., in some countries where Jews were predominantly working in trade, in the professions or in journalism anti-Semitism occurred, in others it did not. Or, in some countries where Jews were predominantly active in small business and unskilled labour anti-Semitism occurred, in others it did not. ${ }^{7}$ Time and again it becomes clear that the occurrence of anti-Semitism was not dependent of this kind of factors.

The question is: How can this phenomenon be explained otherwise? The countries in which anti-Semitism did occur must have something in common that is lacking in the countries where it did not. It is likely and seems the only key to the problem that wherever anti-Semitism occurred an antiJewish stereotype had been fashioned in a far past, and that wherever it did not occur such a stereotype had either not been formed, or had stopped being functional. By functional is to be understood: being helpful to explain problems experienced in a social or an economic context so that they appear

6 The instrinsically anti-Semitic remark "The more Jews, the more anti-Semitism" can easily be shown to be false. It is apparent that the number of Jews in itself cannot be the cause of the antipathy. A (large) number can only reinforce an already existing antipathy, but the origin of the antipathy is independent of it. Not a single German town ever had as many Jewish inhabitants as the city of Amsterdam (before 1940) or Saloniki, where (according to the standards proposed) no anti-Semitism occurred.

7 It is impossible to present a complete argumentation for these observations here. Partly, they rest on a consensus, based on general impressions, partly on research that has not yet been published and that will appear as Pt II of my book. The measuring of anti-Semitism in the terms given can, of course, only be done broadly. In relation to this problem, see also L. S. Dawidowicz, "Can Anti-Semitism Be Measured?", in: Commentary, L (1970), No 1, pp. 36ff. 
understandable and capable of being solved. "Der Jud ist Schuld" (It is the Jew's fault) because he ..., and then one fills in by means of the stereotype what seems useful: the function of the stereotype. Thus, during the agrarian depression German farmers used the stereotype "usury" to blame the Jews for the many foreclosures, the so-called Güterschlächterei or Güterschächterei (schächten = Jewish ritual butchering). American farmers in the 1930's could not do so, certainly did not do so. ${ }^{8}$ Apparently, the problem is to find the answer to the question of what caused the stereotype to come into existence. Basically, this is an historical question, provided historical is understood as "related to processes in time" rather than "related to things that happened in the past". Stereotyping is connected with having a collective opinion, leading to a collective censure and eventually, a collective prejudice. It may be this collective aspect that could lead to an important contribution of historical research to the solution of the problem.

Excellent studies in the fields of social psychology and related social sciences have lead to a brilliant analysis of the anti-Semitic personality as "authoritarian" and the mechanisms of its development from fashioning a prejudice in the personal sphere to the social situations in which such a personality can find its place. ${ }^{9}$ However, the question why a certain scapegoat was chosen to work off one's frustrations, fears, etc., was often answered by: whoever is available. Moreover, these results did not always answer the interesting question of how it can be explained that all kinds of people, who had each acquired their prejudices in different personal situations - e.g., had different parents, so that they reacted to different parent-child conflicts -, came to have collective prejudices and apparently collective rationalizations. Nor has it always become clear how the constituent elements of these rationalizations arose. Why was not every victim accused of whatever came to mind, but were specific, though demonstrably untrue, statements made, whereas other, just as untrue, statements which

${ }^{8}$ See also Pt II of my book, in which this question is treated in detail; for a few references see D. van Arkel, Antisemitism in Austria (Leyden, 1966), pp. 121, 129, 170; id., "Racism in Europe", in: Racism and Colonialism. Essays on Ideology and Social Structure, ed. by R. Ross (The Hague, 1982), p. 25, as well as the literature mentioned there, esp. A Wahrmundt, Das Gesetz des Nomadenthums und die heutige Judenherrschaft, 2nd ed. (Berlin, 1892).

${ }^{9}$ Here only a few classics are referred to: T. W. Adorno et al., The Authoritarian Personality (New York, 1950); Antisemitism: A Social Disease, ed. by E. Simmel (New York, 1946); G. W. Allport, The Nature of Prejudice (Reading, Mass., 1973); J. Rex, Race Relations in Sociological Theory (London, 1970); Race, Science and Society, ed. by L. Kuper (London, 1975); N. W. Ackerman and M. Jahoda, Antisemitism and Emotional Disorder (New York, 1950); C. Y. Glock and R. Stark, Christian Beliefs and Antisemitism (New York, 1966). 
might have "restored respiration" were never made. The most rabid antiSemite, prepared to call Jews the most horrible names, will never say that Jews are lazy. Rarely, if ever, does anti-Semitic literature accuse Jews of being rapists. Blacks, however, are almost always accused of this, but on the contrary very rarely of being swindlers. This process says something about the historical climate in which the prejudice developed. Accordingly, it is the duty of historical research to learn more about the process of collective rationalization by studying the functionality of the prejudice, keeping in mind all the valuable findings of the research in the field of social psychology.

The simplest way to define the field of study is to start from what is probably the most common form of explanation of the anti-feelings, viz., Others are hated by non-Others because they have quality $\mathrm{X}$. If Os are hated for being Os, $\mathrm{X}$ should really be a quality belonging to all Os, and only to them, a quality, therefore, that makes Os into Os. ${ }^{10}$ For this only generic qualities like race, language, religion, class, etc., can be taken into consideration. Applied to Jews, however, at any rate when applied to the period from the nineteenth century onward, none of these characteristics can be $\mathrm{X}$ : no genetic homogeneity exists, nor are Jews a socially homogeneous group; Jews have long since stopped speaking the same language; no longer do all Jews adhere to the Jewish faith. Until the middle of the nineteenth century it was religion that made a Jew into a Jew. It was not the Jewish religion in itself that gave offence, but only the Jewish faith as seen from the point of view of another - the Christian - religion. So it is obvious that European anti-Jewish prejudices can be reduced to the collective censure of the Jews by the Christian Churches. For clarity's sake it must be stressed once again that this censure was a necessary condition, but not in itself a necessary and sufficient condition.

\section{The model (the development and expansion of the stereotype)}

This censure is made in the first instance in accordance with the law of secession friction known from sociology: whenever a minority secedes from a group because it differs from the majority over some point of the group ideology, it will justify its secession by appealing to that common ideology. It will accuse the majority of being unfaithful to its own ideology, which for that reason remains the pillar of its own, new ideology. When in 1776 the American colonies made themselves independent of Great Britain, they

${ }^{10}$ For formal proof see D. van Arkel, G. C. Quispel and R. J. Ross, 'De Wijngaard des Heeren?' Een onderzoek naar de wortels van 'die blanke baasskap' in Zuid-Afrika (Leyden, 1983), and the literature mentioned there. 
did so with an explicit appeal to English Common Law. When more puritan groups seceded from the Dutch Reformed Church, they did so with the argument that they themselves, rather than their old Church, maintained the true doctrine.

So the earliest Christians, who were originally themselves Jews, arrived at the accusation that the Jews were struck with obstinate blindness: that the Jews did not see what they should see because of the promises made to them. In so doing the Christians made the Old Testament, the Jewish tradition, into an undeniable part of their own doctrine, neither to be concealed nor ignored. There was never any doubt about the basic truth of the Jewish scriptures. " The Jews were never accused of having falsified the texts when these became the authentic texts of the Christian doctrine. The friction therefore gave rise to a long series of Christian writings censuring the Jews on the basis of their own texts, which were in that manner declared to be Christian property. E.g., St Augustine: "The Jews are our library slaves, whose burden it is to carry in the texts from which we draw our soul's salvation", ${ }^{12}$ or "The Jews are the witnesses of our truth", the ever returning-Blaise Pascal ${ }^{13}$ - testimonium veritatis argument, by which the Jews are rejected: "The worse they fare, the more is our right proved." 14

This secession friction might have disappeared by compromises or by the gradual decrease of the contradictions, as happens with most other cases of secession friction, if an internal Christian problem had not continued the contradiction. When Christianity became the state religion of the Roman Empire, many people became Christians for material reasons, for jobs, without a strong inner conviction, but through that small amount of Christianity they got into touch with Jewry. However, their faith lacked sufficient certainty, or real interest, for them to take over the censure completely. As a consequence, a great many of them, especially in the large cities, went to the synagogue instead of to the church. ${ }^{15}$ This was all the

11 J. Parkes, A History of the Jewish People (Harmondsworth, 1964), p. 63.

12 M. Simon, Verus Israel. Etude sur les relations entre Chrétiens et Juifs dans l'Empire Romain (135-425) (Paris, 1948), p. 94. A similar idea is to be found, e.g., in Justin Martyr, see A. L. Williams, Adversos Judaeos. A Bird's Eye View of Christian Apologiae until the Renaissance (Cambridge, 1935), pp. 31ff.; Parkes, A History, p. 62. 13 B. Pascal, Pensées, ed. by L. Brunschvicg, No 640.

14 W. Sulzbach, Die zwei Wurzeln und Formen des Judenhasses (Stuttgart, 1959), p. 29; Simon, Verus Israel, op. cit., p. 268; J. Isaac, Genèse de l'Antisémitisme. Essai historique (Paris, 1956), pp. 166ff.

15 On proselytism and Judaizing see, inter alia, R. Anchel, Les Juifs de France (n.p., 1946) pp. 23ff.; F. Lovsky, Antisémitisme et Mystère d'Israël (Paris, 1955), pp. 35ff., 139ff., 161; L. Poliakov, Histoire de l'Antisémitisme, I: Du Christ aux Juifs de Cour (Paris, 1955), p. 39; Simon, Versus Israel, pp. 175, 336, 432; Williams, Adversus Judaeos, op. cit., pp. 132, 338; Parkes, A History, p. 62. 
easier because in the Codex Theodosii it was laid down expressly that beside the Christian faith the Jewish religion was the only religio licita ${ }^{16}$ the only legal religion, when all other religions had been proscribed and their temples closed. Its being their own cornerstone compelled the Christians to legalize the Jewish religion, be it with limitations such as the prohibition of building new synagogues. ${ }^{17}$

When in spite of these limitations many believers strayed and entertained good relations with Jews, other measures were called for. This problem forced many theologians of the fifth and later centuries into their invectives against the Jews, which are also found in Gaul at a much later date. ${ }^{18}$ This was the basis of Chrysostom's anti-Jewish sermons. In the terms of Marcel Simon: it led to theological hatred of Jews as a function of lay philoSemitism. ${ }^{19}$ The better the relations between Jews and lay Christians, the more fervent the invectives. The sheep had to be separated from the goats: segregation. Segregation, which appears to be a symptom of all kinds of racism, had to be imposed from the top. In one country this was not necessary: in Egypt. In Alexandria segregation already existed, which can be explained in part by the pre-Christian conflict about holy (or unclean) animals, a conflict that reminds one of that between Moslems and Hindus in India. Egypt had long been a source of anti-Jewish stories for pre-Christian Greek and Latin authors, e.g., Tacitus. ${ }^{20}$ Among the Roman elite a certain anti-Jewish tradition existed, which, however, seems discontinuous and of marginal significance for the development of anti-Semitic prejudice. ${ }^{21}$

If it is now surmised that besides stigmatization by the Church segregation is the second necessary condition and that together they are sufficient, Egypt would be bound to have been the first to experience a mass antiJewish reaction. In effect Egypt was the first and, for some time, the only Christian country where Jews were persecuted on massive scale: in 414 a massacre took place, instigated by Cyril, Patriarch of Alexandria, which

16 Lovsky, Antisémitisme, p. 187; J. Juster, Des Juifs dans l'Empire Roman. Leur condition juridique, économique et sociale (2 vols; Paris, 1914); Simon, Verus Israel, pp. 156-57.

${ }_{17}$ S. W. Baron, A Social and Religious History of the Jews, 2nd ed. (12 vols; New York, 1957), III, pp. 8, 10, 30, 189; Lovsky, Antisémitisme, pp. 36, 108, 109, 164, 179; Parkes, A History, p. 64; Simon, Verus Israel, p. 351.

${ }_{18}$ See note 15; B. Blumenkranz, Juifs et Chrétiens dans le Monde occidental 430-1096 (Paris, 1960); B. Bachrach, Early Medieval Jewish Policy in Western Europe (Minneapolis, 1977).

19 Simon, Verus Israel, p. 263.

20 E.g., Tacitus, Historiae, V, 4.

21 In this framework a complete argument is impossible. See Pt I of my book. For a summary of the discussion see, e.g., Poliakov, Histoire de l'Antisémitisme, I, op. cit.; Isaac, Genèse de l'Antisémitisme, op. cit. 
the city prefect Orestes was unable to prevent and which spread to all those who took the part of the Jews, witness the horrible killing of the philosopher Hypatia, who was stripped alive of her flesh with shells on the beach. ${ }^{22}$

This seems to confirm the hypothesis that prejudice as a cluster of stereotypes came into being when leaders with sufficient moral (?) authority stigmatized the group concerned, and this stigma was no longer corrected by daily interaction. It is submitted that when there is any doubt about this authority and/or when there is sufficient correction by social relations, the phenomenon of hatred of the Jews will not occur. This leads to the new hypothesis: prejudice will be fashioned the more easily when that authority, both moral and supported by the worldly strong arm, is imposed in an effective Cäsaropapismus.

As the situation in Egypt is no longer relevant after its occupation by the Arabs, we can try and check this by the situation in Byzantium, because there an effective bureaucracy was maintained as a result of the continuance of a money economy with a well-run fiscal system, which carried out the combined will of State and Church, more or less independent of the whims of the Emperors who succeeded one another by deposition or murder in various palace revolutions. This possibility would be enhanced when maintaining orthodoxy was government policy.

It can be shown that in Byzantium after Justinian segregation between Christians and Jews was imposed effectively (including the creation of separate Jewish residential districts), and that persecutions did occur ${ }^{23}$ when government policy seemed to make them necessary. On the other hand segregation did not lead to a specification of Jewish economic positions, and especially money lending did not become a particularly Jewish activity as in the West at a later date. The reason is simply that the State itself met this need. In economic affairs the Jews were not restricted in any way. All economic functions, all trades were open to them, on the condition that they did not discuss religious subjects with Christians, did not try to convert Christians, and did not derogate Christ and his Church. In order to supervise this an imperial official was always present at the services in the synagogue, while the Septuagint was the only text permitted, and the Talmud and the Hebrew Torah, which these officials could not read, were prohibited.

Nonetheless, the new hypothesis was falsified. No expanding system of

22 S. Dubnov, History of the Jews, transl. by M. Spiegel (5 vols; South Brunswick, N.J., 1967-73), II, pp. 193f. For a very vivid description see E. Gibbon, The Decline and Fall of the Roman Empire, ed. by O. Smeaton (6 vols; London, 1946), V, pp. $11 \mathrm{ff}$.

${ }_{23}$ Dubnov, History of the Jews, II, pp. 210f., 527ff.; Baron, A Social and Religious History of the Jews, op. cit., III, p. 3; Lovsky, Antisémitisme, p. 116. 
stereotypes was fashioned. There merely persisted the existing theological stereotype of the obstinately blinded Christ murderers, deicides, who had failed in their salvationist task. Not only did no economic accusations arise against the Jews that they were moneygrubbers or capitalists, which is understandable, but neither did those notions which arose elsewhere as a result of popular beliefs about ritual murder, defiling the host, or the remarkable idea that the Jews abused the magic force of baptism and the symbol of salvation for their evil purposes. So there were no images of the Jews as poisoners, black magicians, conspirators who abused their economic power (as usurers) for their evil practices, and above all no massacres instigated by the ordinary people. Persecution was the privilege of the authorities, who did not grant it to others if it did not suit them.

This was the special controlled character of anti-Semitism in Byzantium: name calling, jeering, fisticuffs, but no more - the autocratic government kept strict supervision. ${ }^{24}$ That gives grounds for assuming that for the expansion of the stereotype a third condition is required: terrorization of the discriminator. This is the circumstance well-known from other racist situations of "Whoever does not co-operate, does not share our view, is wrong and will suffer for it." To be a "nigger-lover" is almost as bad as being a "nigger", and is punished in the same way. Fear of punishment compels participation. Whoever does not join in a lynching party or protests against it, is in acute danger. When anyone is driven by fear to take part in an atrocious and unjustified punishment of a person who in his view is innocent, he suffers from a sense of guilt that he can only get rid of by convincing himself that the "nigger" is guilty after all. He is being terrorized into being a discriminator, and once on this way he has to go on. There are numerous variations of this. Not many people have the courage to resist this terror, though there are always a few.

For it to be useful as an explanation the terrorizing mechanism has to be tested. In the case of anti-Semitism this is possible. For instance, it can be observed time and again in the period of the First Crusade. Here one example will be described. On Whitsunday 1096 the "crusaders"/murderers lay before Treves. In a body they came to the church, where on that

${ }^{24}$ See my book. For a better understanding of the Byzantine situation the following works are of great importance:G. Ostrogorsky, History of the Byzantine State, 2nd ed. (Oxford, 1968); id., "Agrarian Conditions in the Byzantine Empire in the Middle Ages", in: The Cambridge Economic History of Europe, I, 2nd ed., pp. 205ff.; S. Runciman, "Byzantine Trade and Industry", ibid., II, pp. 103ff.; A. A. Vasiliev, History of the Byzantine Empire (2 vols; Madison, 1928); A. Sharf, Byzantine Jewry from Justinian to the Fourth Crusade (London, 1971); J. Starr, The Jews in the Byzantine Empire (6411204) (Athens, 1939) (documents). 
Sunday the Bishop himself preached in the spirit of Pentecost. So he took a clear stand against the massacre of Jews committed elsewhere, and courageously impressed upon his audience the un-Christian character of their acts. He insisted upon the age-old doctrine that God is indeed awaiting the conversion of the Jews, but that this conversion is to be brought about by loving persuasion and not by violence. The lesson did not please the crusader audience, which protested so violently that they came to blows. The Bishop was taken prisoner and threatened. The episode ended with the Bishop giving the order to hand over all the Jews who had taken refuge in the episcopal palace. ${ }^{25}$

Terrorizing can occur when the authority of the State is not effective enough to attain the monopoly of violence, ${ }^{26}$ or when the State itself makes use of the terrorizing mechanism, as in Nazi Germany and Tsarist Russia. The following new hypothesis can now be made. In the early Middle Ages, when the money economy broke down in the West, there was on the one hand no apparatus effective enough to impose segregation and, implicitly, the acceptance of stigmatizing. On the other hand there was insufficient monopolization of violence to prevent the terrorizing process. So it was impossible to impose from above, within legal restrictions, the theological stigma and segregation, but if they came to be accepted in another way, as a result of this insufficient monopolization of violence the authorities were unable to prevent its expansion by terrorizing. Therefore, in order to explain the acceptance of a stigma it is necessary to look for an increase of social distance independent of Church and State or, in other words, for such a degree of decreasing interaction that the stigma is no longer corrected by it.

Theoretically, this hypothesis can be checked in three ways. Firstly, one can imagine the case in which the stereotype expands in a situation in which social distance is small. This leads to the conclusion that social distance is insufficient as an explanation. Secondly, a case can be imagined in which there is no expansion of the stereotype, though social distance does exist, stigmatizing has taken place and terrorizing of the discriminator is present. If this is true, then the three conditions are not necessary and sufficient. But so far no historical situations are known in which one of these cases has occurred. The third method of checking is left as the only one possible. It consists of a) proving that there is a functional relation between the increase of social distance and the expansion of stereotyping (to be measured by the

2s J. Aronius, Regesten zur Geschichte der Juden im Fränkischen und Deutschen Reiche bis zum Jahre 1273 (Berlin, 1902), No 189.

${ }^{26}$ G. van Benthem van den Bergh, De Staat van Geweld. Essays (Amsterdam, 1980), p. 57. 
increasing frequency and size of persecutions), and b) checking whether a (calculated) acceleration of the increase of social distance does in fact coincide with an (expansion of) stereotyping.

To measure the increase of social distance a method of calculation was devised to express social distance as a function of the number of Jewish groups (social, economic, judicial, military, etc.) that interacted with corresponding non-Jewish groups. The more frequent these interactions, the smaller the social distance and vice versa. From this an exponential relation appears to exist, which, roughly speaking, means that the social distance per geographical unit more than doubles with each disappearing interacting group (the calculation provides a unit of social distance). In addition, the calculation shows that a similar relation exists between the growth of social distance and the increase of the number of (new) nonJewish groups that are not interacting with Jews, either occupationally or otherwise. In other words, the definition of social distance implies a method of calculation which shows that the more the opportunities for interaction decrease, the more quickly is a negative stereotype fashioned and/or expanded.

This is not as trivial as it may sound when the disappearance of relations between formerly interacting groups was not the consequence of animosity, but the result of a socio-economic process independent of stigmatizing, and when the number of interactions did not run parallel with the number of interacting groups. If this proportionality did exist, the simple disappearance of interacting groups would be sufficient to explain the fashioning of the stereotype, and a more detailed quantitative analysis would be superfluous. If, however, the number of interactions were to decrease proportionally somewhat more quickly than the number of interacting groups, and if the decrease of the possibilities for interacting for each group was not always equal, this inequality would be a possible explanation for the relatively sudden change in the relations between Jews and non-Jews. For these reasons it is worth while to take a closer look at the various aspects of the relations between groups.

If in a given area at a given time the Jewish group (A) consists of a number of subgroups, such as army groups, occupational groups, housing groups, etc. (represented as $B^{\prime}, C^{\prime}, D^{\prime}$, etc. $-B^{\prime}=A_{B^{\prime}}, C^{\prime}=A_{C^{\prime}}, D^{\prime}=A_{D^{\prime}}$, etc.), each of which entertains close and open relations with the corresponding non-Jewish groups B, C, D, etc., a complex network of relationships will come into existence. This can be analyzed. The relations between $B$ and $B^{\prime}$, in which $B$ is the non-Jewish counterpart group (CP) of the Jewish group $B^{\prime}$, when represented as $A B\left(=B^{\prime} B\right.$ or $\left.A_{B^{\prime}} B\right)$, means that members of $B$ will co-operate so closely with Jews that for that reason they 
will not be inclined to have hostile feelings towards other Jews whom they do not meet, or towards the Jews as such, when a hostile stereotype has not yet become generally accepted. The deductive inference is positive, because the inductive inference is positive. In general, it holds good that people are always inclined to think their experiences with some members of another (ethnic) group (which they tend to unify: inductive inference) applicable to all other members of that group by way of generalization, and thus to the group as such (deductive inference) in a positive or a negative sense. ${ }^{27}$ As a matter of course, this also holds good for $\mathrm{AC}\left(=\mathrm{C}^{\prime} \mathrm{C}\right.$ or $\left.A_{C}, C\right), A D\left(=D^{\prime} D\right.$ or $\left.A_{D^{\prime}} D\right)$, etc.

However, not only relations between corresponding groups are concerned, e.g., Jewish and non-Jewish farmers, but also between non-corresponding groups. Farmers as such have close social relations, often of a nature of mutual dependence, with, e.g., farriers, millers or butchers, and on this basis may share many social concepts with these groups. Brewers can share interests with coopers, coppersmiths and farmers, etc. In some circumstances there can be a convergence of ideas between weavers, spinners and fullers, while in other circumstances they may be at odds. This possible unity of ideas can lead to models of interaction between three or more groups.

If Jews are members of these groups, or rather, when such groups consisting of non-Jews do belong to the category of CPs of Jewish subgroups, these multiple patterns of interaction assume the character of $\mathrm{ABC}\left(=\mathrm{B}^{\prime} \mathrm{BC}^{\prime} \mathrm{C}\right.$ or $\left.\mathrm{A}_{\mathrm{B}}, \mathrm{BA}_{\mathrm{C}^{\prime}}, \mathrm{C}\right)$, as well as relations of the type $\mathrm{B}^{\prime} \mathrm{C}^{\prime}$ (= $\left.A_{B}, A_{C^{\prime}}\right)$ and of the type $B C$. The former of the last two - the interaction between Jewish (occupational) groups - has no significance for the problem being discussed. The latter must have occurred very frequently on account of the small number of Jews rather than because of animosity. There is no conceivable reason why two CPs would co-operate on the basis of deliberate exclusion of Jews, even less when the nature of the co-operation is based on considerations that have no connection with religion. When $\mathrm{BC}$ occurred it was most probably at worst neutral as far as stigmatizing was concerned, while the relations $\mathrm{ABC}$ would correct the stigma positively, just as would the other relations between more groups. (Again: deductive inference is positive when inductive inference is.)

One aspect of these multiple relations merits special attention. It is significant that members of the $\mathrm{CPs} B, \mathrm{C}$, etc., in the relations $\mathrm{AB}, \mathrm{AC}$,

${ }^{27} \mathrm{H}$. Wilke, "Vooroordeel: begripsvorming, de toekenning ervan en benaderingen", in: Vooroordeel en discriminatie, ed. by G. J. Kok, A. van Knippenberg and H. Wilke (Alphen aan den Rijn, 1979), pp. 13ff. 
etc., have a different conception of Jews than members in the relations $\mathrm{ABC}, \mathrm{ABCD}$, etc. Valuing Jewish colleagues within one co-operating team is not identical with the pleasant realization, experienced when discussing common problems with members of groups of a different kind from one's own, that Jews are present in all types of co-operating groups. This leads to varying, and thus more perceptive kinds of appreciation. Therefore, as a result of the existence of $A_{B^{\prime}}, A_{C}$, and their occupational colleagues (CPs) $B$ and $C$, four qualitatively different relations can be expected: $A B, A C, B C$ and $A B C$, and where there exist $A_{B^{\prime}}, A_{C^{\prime}}$ and $A_{D^{\prime}}$, the eleven relations 1) $\mathrm{AB}, 2$ ) $\mathrm{AC}, 3) \mathrm{AD}, 4) \mathrm{BC}, 5) \mathrm{BD}, 6) \mathrm{CD}$, 7) $\mathrm{ABC}$, 8) $\mathrm{ABD}$, 9) $\mathrm{ACD}, 10) \mathrm{BCD}$ and 11) $\mathrm{ABCD}$. Of these 1, 2, 3, 7, 8, 9 and 11 most probably act correctively in case of stigma, while 4, 5, 6 and 10 are neutral in this respect, and certainly will not further it.

However, no society has ever been as peaceful and harmonious as the model presupposes so far. Some economic, social, housing groups, etc., each involved in co-operation with corresponding Jewish groups, may have met with quarrels and conflicts, with differences of class or interest. Fullers and weavers can be in conflict. If Jews belong to both antagonistic groups, or rather, if the two non-Jewish antagonistic groups belong to the category of CPs of Jewish subgroups, then the conflict may prevail over inter-Jewish solidarity, or it may not. In the first case, in a pre-stereotype era the participation of Jews in the conflict will not have any consequences for any of the non-Jewish groups involved in view of their idea of the Jew as such, but at the most it may lead to the idea that some Jews are all right and other Jews are not, in the same way as some non-Jews are all right and others are not. There is no reason to assume that Jews who are loyal to the common cause should be considered as exceptions. Indeed, the Jews who have served the cause of the enemy are more likely to be seen as exceptions.

As has already been indicated, in the case of one Jewish subgroup, and consequently one $\mathrm{CP}$, the possible number of interactions is $1, \mathrm{AB}$. In the case of two Jewish subgroups the total number of interactions with $\mathrm{CPs}$ and between $\mathrm{CPs}$ is four: $\mathrm{AB}, \mathrm{AC}, \mathrm{BC}$ and $\mathrm{ABC}$, three of which are correcting stigma and one at worst neutral. In the case of three Jewish subgroups there were, as was shown, 11 such relations ( 7 correcting and 4 neutral), which does suggest that the number of correcting interactions increases more quickly than the number of interacting groups.

In order to prove this for any number of interacting groups, a general equation must be formed. This can be done by calculating the number of interactions for $n$ interacting groups, or rather, because so far the Jewish group $\mathrm{A}$ has been considered as an interacting group, for $\mathrm{n}-1$ Jewish 
subgroups, and consequently n-1 non-Jewish CPs. As the total number of relations is equal to the sum of the number of relations that can exist between 2, 3, 4 etc. Jewish subgroups and their CPs, the total equals the number of combinations that can be made. If there are $\mathrm{n}$ groups, the first, A, can be combined with $n-1$ others to a combination of two. The same is true for all the others, so that altogether $n(n-1)$ combinations of two can be made. Because, in this way, continually identical combinations are made: $\mathrm{AB}$ and $\mathrm{BA}, \mathrm{AC}$ and $\mathrm{CA}, \mathrm{BC}$ and $\mathrm{CB}$ etc., $\mathrm{n}(\mathrm{n}-1)$ must be divided by two to get the possible number of non-identical combinations of two.

The same has to be done to make combinations of combinations of two with a third group into combinations of three, for which only $n-2$ groups are available, because then there are three ways to combine $\mathrm{A}, \mathrm{B}$ and $\mathrm{C}$, viz., $\mathrm{ABC}=\mathrm{BAC}, \mathrm{BCA}=\mathrm{CBA}$ and $\mathrm{ACB}=\mathrm{CAB}$. The total number of possible, non-identical combinations is $\frac{\mathrm{n}(\mathrm{n}-1)(\mathrm{n}-2)}{2.3}$. The same holds true for all other combinations. With $\mathbf{n}$ Jewish groups there are $\mathrm{n}-1$ types of combinations. The total number of relations, $S_{n-1}$, comes to $2^{n}-(n+1)$.

More relevant is the number of relations in which the Jewish groups are concerned, leaving out the neutral ones. If there are two Jewish groups, including the entire Jewish group and one subgroup, the Jewish group has one relation with a non-Jewish group through that subgroup, AB; if there are three Jewish groups, when calculated in the same way, there are three working relations, $\mathrm{AB}, \mathrm{AC}$ and $\mathrm{ABC}$. If there are $\mathrm{n}$ groups ( $\mathrm{n}-1$ subgroups and $n-1$ CPs), there are $n-1$ relations in combinations of two. These can be made into combinations of three with the remaining $\mathrm{n}-2$ groups, but, since there are two ways to make the combination $A B C$ etc., viz., $A B+C$ and $\mathrm{AC}+\mathrm{B}$ (the combination $\mathrm{BC}$ has been excluded), this number must be halved in order to get the real number of non-identical combinations of three. The sum is $2^{n-1}-1$. The number of relations that CPs may have among themselves, the neutral relations, would then be $2^{n-1}-n$. In other words, there must be at least two interacting Jewish subgroups, or $n=3$, before there can be neutral relations as a first defence.

In this way it is possible to calculate the functional relation between the increase of social distance and the increase of stereotyping. In principle, this relation can be tested historically. The possibility for testing is strengthened if the model has a threshold value predicting a breakingpoint. That is to say, if it is possible to calculate that below a certain value of social distance no discrimination occurs, whereas above that value it always does. When applying the test, it can be checked if the conditions that can be proved empirically to have existed in order to reach the threshold do coincide with an acute turn in the attitude towards the Jews. When such 
a threshold value is calculated, the explanatory value of the model is increased at the same time. In that case the model can explain the mysteriously quick change from the extremely favourable relations between Jews and non-Jews in the Merovingian and Carolingian eras to the numerous mass persecutions of the eleventh century - notably against the wishes of the clergy, who protested, as, e.g., Agobard and Amulo, Archbishops of Lyons, but also Council edicts. The model could also explain why in mediaeval England anti-Jewish feelings developed within a century after the first settlement of Jews, whereas the same process took at least six centuries in Gaul. The model can also explain the late, but ferocious hatred of the Jews in the parts of Poland that belonged to the Russian Empire before the First World War, and make clear why in Holland, in opposition to other parts of the Netherlands, the hatred of Jews was relatively rare, or why an autochthonous anti-Semitism did not exist in Italy, Greece or Bulgaria.

At what point does this threshold exist? In the space of this article it is impossible to present the whole of the calculation, but its result can be given in summary. The threshold turns out to lie at that particular value of social distance (SD) as expressed in the number of interactions of non-counterpart groups (NCPs, groups that do not know interactions with Jewish groups) among themselves, plus the number of interactions of these groups with CPs B, C, D on the one hand and the interactions of the number of CPs among themselves on the other hand: $I_{N C P} / I_{C P}$, when it equals the frequency of friendly interaction ( $F$, expressed in the number of Jewish subgroups and interacting non-Jewish groups). The threshold lies at the point where SD equals $F^{28}$

Although the intention of this article has been to show the way in which the approach by means of a model can be applied rather than to present the methods of testing it with historical material, it may be useful to show something of the empirical checking as well. An early historical situation that can be checked is the sudden beginning of the persecutions of the Jews at the end of the eleventh century. According to the argument elaborated above it would be necessary that immediately before or at the beginning of the persecutions an increase of social distance had occurred, expressed in a rapid disappearance of Jewish subgroups and the beginning of an increase of non-interacting groups of non-Jews. These processes must have taken

${ }_{28}$ The threshold values lie on the curve $S D=2^{n-L}-1$. The area between this curve and the $n$ axis denotes the increase or decrease of the chances of non-discrimination. That area is calculated at $1.443\left(2^{n-1}-1\right)-(n-1)$ by using integral calculus. The disappearance of one Jewish subgroup, therefore, implies that the chances of non-discrimination are more than halved, and vice versa. 
place independently of stigmatizing and terrorizing.

It can be shown that such processes did in fact occur. To begin with, it is not so difficult to make clear that after the ninth century Jews disappeared as landowners and therefore from agrarian activity, most probably because Jewish land was allodial and never feudal (Jews could not swear the Christian oath that was required) and in this period the tendency was for all forms of allodial ownership to disappear in the process of feudalization. Aronius's famous collection of calendars ${ }^{29}$ contains a large number of cadastral data stating about the ownership of a certain piece of land in the ninth and tenth centuries that a short time before it still belonged to a Jew, or information of a similar nature. This disappearance from landownership sharply contrasts with earlier statements, e.g., a letter of Pope Stephen III complaining about Jewish allodia that were worked in co-operation with Christians, ${ }^{30}$ often neglecting the observation of the sanctity of the Sunday, but never of the Sabbath, and similar complaints of the Archbishops of Lyons, Agobard and Amulo, contemporaries of Louis the Pious. ${ }^{31}$ The sudden disappearance from landownership is so striking that it gave rise to a discussion among economic historians about the question of whether in this could be found the basis of the formation of Jewish trade capital.

In addition, it is feasible to assume that a specification of Jewish economic positions took place, because the Jews did not participate in the earliest guilds. This cannot be proved in detail, but it seems very probable in view of Coornaert's analyses of the earliest forms and their semi-pagan character. ${ }^{32}$ The socially marginal position of early-mediaeval traders as a result of the prevailing insecurity - lack of a monopoly of violence -, their being united in Hanses, their uneasy status in society, in which the Jews could not but share to their disadvantage, cannot be denied after Pirenne's, and more recently Le Goff's, studies about this, or after Niermeyer's dissertations concerning Alpertus of Metz's De Diversitate Morum. ${ }^{33}$ Jews

${ }^{29}$ Aronius, Regesten, op. cit., passim.

31) Ibid., No 67.

31 Ibid., Nos 84-97, 105-11.

${ }_{32}$ E. Coornaert, "Les Ghildes médiévales (Ve-XIV siècles). Définition. Evaluation", in: Revue Historique, CXCIX (1948), pp. 22ff.; M. H. Caffiaux, "Mémoire de la frairie de la halle basse de Valenciennes", in: Mémoires de la Société des Antiquaires de France, XXXVIII, Fourth Series, VIII (1877), pp. 1ff.

${ }^{33}$ See notably H. Pirenne, Les Villes et les Institutions urbaines (Paris, Brussels, 1939); J. F. Niermeyer, "Judaeorum Sequaces, Joodse kooplieden en Christelijke kooplieden. Bijdrage tot de ontstaansgeschiedenis van de Lotharingse burgerij (elfde eeuw)", in: Mededelingen der Koninklijke Nederlandse Akademie van Wetenschappen, Afd. Letterkunde, New Series, XXX (1967), pp. 167ff.; J. Le Goff, "Au Moyen Age: Temps de l'Eglise et temps du marchand", in: Annales. Economies, Sociétés, Civilisations, XV (1960), pp. 417ff. 
were doubly victimized. Economic contraction also played am important part.

Social distance as a result of economic contraction can be well imagined during the ninth and tenth centuries. In the North-West of France and neighbouring districts economic activities had reached a very low level, as a result of their being exposed to the massacre and plunder by the Vikings, as well as the high ransom paid to prevent further ravages. The serious demographic consequences and the resulting political chaos, as well as the loss of precious metals led to a degree of torpor in the North-West, from which it did not recover until the eleventh century, and then only slowly. Trade and industry disappeared almost completely, Dorestad lay in ruins; the once flourishing city of Quentovic-on-the-Canche was so completely devastated that its exact location cannot yet be established. ${ }^{34}$ Even if the Viking raids were something of a blessing in disguise in that they contributed greatly to a new economic orientation by the considerable expansion of the total trading area compared to any former period, the rise of new centres of trade grouped around the "Viks", and the re-appearance of the robbed gold, ${ }^{35}$ it remains true that the favourable effects did not appear until a later stage. Someting similar occurred in the South of France. There the local inhabitants, as far north as Lyons, were killed, burnt out and robbed by Moslems from their base at Garde Freinet. ${ }^{36}$ Moslems brought trade across the Alps to a standstill and destroyed most ports on the North coast of the Mediterranean.

When the economy recovered, it happened in a way that was unfavourable to the Jews, especially in the North. The guilds that existed there were in fact originally pagan, Germanic kinship organizations, whose primary purpose was the collection of wergeld, while their secondary function was mutual self-help and looking after the dependents of brothers after their death. As a matter of course, the Jews had kept their distance from the pagan-like libations and ritual drunkenness at funerals, descriptions of which are to be found in literature, and their heathen ritual - something that the clergy also approached with distrust. Thus a different form of specifically Jewish economic functioning can be explained. When these organizations, called oligopolistic at a later stage, became economic organizations, this meant that Jews were kept outside the production and sale of

${ }^{34}$ N. J. G. Pounds, An Economic History of Medieval Europe (London, New York, 1974), p. 339.

${ }^{35}$ Ibid., pp. 86ff.; R. Latouche, The Birth of Western Economy. Economic Aspects of the Dark Ages, transl. by E. M. Wilkinson (London, 1967), pp. $211 \mathrm{ff}$.

36 Pounds, An Economic History of Medieval Europe, pp. $89 \mathrm{ff}$. 
all products made by the members of the guilds and were limited to their own market for these trades.

The specification of Jewish economic positions can be followed in rabbinic statements from the early eleventh century, e.g., from Troyes, about money lending. This was no less a problem to Jews in view of the fact that the Christian prohibition of usuria was based on Old Testament texts. Thus, an interesting inter-Jewish case is mentioned, whether a piece of land of a certain value should be rated as high for internal Jewish taxes as the same value in cash, taking into account that the latter could yield a higher profit ${ }^{37} \mathrm{~A}$ typical example of a transitional phase. It is also significant that Bernard of Clairvaux no longer uses the word judaizare to mean "following Jewish rites", but in the meaning of "lending at interest". ${ }^{38}$ In the same period Abelard also wrote about the interest required by Jews. ${ }^{39}$

At the time when an amount of social distancing occurred that can be substantiated in this way, the great eruptions of 1096 took place, preceded by warning rumbles in the early eleventh century, described by the chronicler Raoul Glaber ${ }^{40}$ As already stated, it was so much a bolt out of the blue in the Rhineland that rabbis in Mayence did not understand the message when they received the warning from their fellow Jews in France, and answered that they would pray for their French brothers. Jews were actively supported, not only by all the Bishops of the Rhineland, who took up arms against the so-called crusaders, but also by the population, who helped the Jews to go underground. The moving Jewish memorial literature leaves no doubt about this. ${ }^{41}$ The fact that Peter the Hermit, Walter Sans-Avoir and their troops had long since left the Rhineland for the Holy Land before the massacres started, the fact that they had not committed any unlawful action against the Jews while passing through the area ${ }^{42}$ makes it clear that a traditional interpretation of these massacres as "religious paroxysm" is doubtful, to say the least.

From this time onwards terrorizing the discriminator - clearly to be seen from numerous examples - made stigmatizing into a variable dependent on

${ }^{37}$ R. Chazan, Medieval Jewry in Northern France. A Political and Social History (Baltimore, London, 1973), p. 15.

3* Aronius, Regesten, No 244.

34) Chazan, Medieval Jewry in Northen France, op. cit., p. 33.

4) Aronius, Regesten, No 142. See also R. Glaber, Les cinque livres de ses histoires (9001044), ed. by M. Prou (Paris, 1886).

t1 A. Neubauer and M. Stern, Hebräische Berichte über die Judenverfolgungen während der Kreuzzüge (Berlin, 1892).

${ }^{22}$ S. Runciman, A History of the Crusades (2 vols; Harmondsworth, 1971), I: The First Crusades and the Foundation of the Kingdom of Jerusalem pp. 121ff.; Neubauer and Stern, Hebräische Berichte, pp. 25, 131, mention that Peter asked for food from the Jewish communities while on his passage. Nothing further happened. 
social distance. Hence the highly significant fact that from this time stigmatizing increasingly assumed an "economic" coloration, to be seen from the way in which "usury" began to form part of anti-Jewish stereotyping, by the side of popular phantasies about ritual murder and desecrating the host, which were derived from theological arguments.

Apparently, the specification of Jewish economic positions as it occurred in Western Europe in the tenth and eleventh centuries was essential. Where such a specification did not occur, as in Southern and Central Italy under the influence of the Islam and the Hohenstaufens, but where as a result of an early recovery of the money economy the authority of the State developed at an early stage, setting restrictions whenever reasons of State or economic interest required that - the more autocratic, the less antiJewish as in most Italian States ${ }^{43}$-, no stereotype was fashioned. Nowhere in Europe before the French Revolution did the Jews enjoy as many liberties and so unrestricted a life as, e.g., in Tuscany. With a rare, not even quite certain, exception like the Venetian Ghetto (the etymologically unclear name of a district that was to gain a general meaning), Italy remained so free from popular hatred of the Jews up to the time of the Fascists that, according to, e.g., Renzo De Felice, Mussolini lost many of his adherents when he started his anti-Semitic campaign in 1938, be it under German pressure or not. ${ }^{44}$ Rome itself, the centre of Christianity, had remained free from the pest of hating the Jews during the whole of the mediaeval period, because Popes as worldly rulers, with locally often effective power, followed the example of their great predecessor, Gregory the Great, who kept segregation within strictly theological terms and allowed the Jews what had not been forbidden to them according to the old Roman laws. ${ }^{45}$ Compare this to, e.g., Richard I of England, who was

${ }^{43}$ C. Roth, The History of the Jews of Italy (Philadelphia, 1946), pp. 115-16. Other important works on the history of the Italian Jews are, inter alia, U. Cassuto, Gli Ebrei a Firenze nell'Età di Rinascimento (Florence, 1918); H. Vogelstein, History of the Jews in Rome (Philadelphia, 1940); E. Kantorowicz, Kaiser Friedrich der Zweite, facsimile ed. (Düsseldorf, 1973); M. A. Shulvass, The Jews in the World of the Renaissance (Leyden, 1973); A Milano, Storia degli Ebrei in Italia (Turin, 1963); G. Caro, Sozial- und Wirtschaftsgeschichte der Juden im Mittelalter und der Neuzeit (2 vols; Frankfort/M.. 1924).

4 R. De Felice, Storia degli Ebrei Italiani sotto il fascismo, 2nd ed. (Turin, 1972), p. 302 and passim. See also M. Michaelis, Mussolini and the Jews. German-Italian relations and the Jewish question in Italy, 1922-1945 (Oxford, 1978).

${ }^{45}$ Two important sources about the relations between Jews and Popes are M. Stern, Urkündliche Beiträge über die Stellung der Päpste zu den Juden (2 vols; Kiel, 1893-95); S. Grayzel. The Church and the Jews in the XIIIth Century (Philadelphia, 1933). See aiso S. Grayzel, "The Papal Bull Sicut Judeis", in: Studies and Essays in Honor of Abraham A. Neuman, ed. by M. Ben-Horin, B. D. Weinryb and S. Zeitlin (Leyden. 1962). 
furious at those who had made the great massacre among the Jews of York in 1190 because they robbed him of the revenues from "his" Jews, but who was completely unable to punish the guilty. ${ }^{46}$

Another place where testing is possible is the Netherlands. The model predicts that Holland, and especially Amsterdam, where no Jews had been living during the Middle Ages, would not have developed a negative stereotype, in contrast to other parts of the Netherlands, such as Brabant and the IJssel valley. In the latter two Jews were severely persecuted, in particular in the years 1349 and following, the years of the Black Death ${ }^{47}$ In Holland, to which Jews from the Iberian Peninsula immigrated in the late sixteenth century as Marranos, "New Christians", these were welcome, because they brought commercial and other expertise with them, as well as good commercial relations. In early-capitalist Amsterdam they were gladly permitted to participate in all modern branches of the speedily developing economy. So they got involved in the diamond trade and manufacturing, a result of their Brazilian connections, in book printing, in brokering, in banking, in trans-oceanic trade and shipping, but they were not allowed to work in branches of industry under the control of the old guilds. ${ }^{48}$

That early-capitalist spirit did not penetrate so strongly into the more traditional province of Overijssel, badly situated for modern trade, where cities like Zwolle, Deventer and Kampen had known great prosperity in the Middle Ages. Jews, who had marginally participated in this prosperity, in a situation in which the NCPs were probably twice as numerous as the CPs, had in the end become victims. The model predicts that in Holland little anti-Semitism would occur, other than cold-shouldering or sneering, ${ }^{49}$

46 R. B. Dobson, The Jews of Medieval York and the Massacre of March 1190 (York, 1974); for a general background see J. Jacobs, The Jews of Angevin England. Documents and Records from Latin and Hebrew Sources (London, 1893); C. Roth, A History of the Jews in England, 3rd ed. (Oxford, 1978); H. G. Richardson, The English Jewry under Angevin Kings (London, 1960).

${ }_{47}$ Germania Judaica, ed. by J. Ellbogen, A. Freimann and H. Tykocinski, facsimile ed. ( 2 vols; Tübingen, 1966), II: Von 1238 bis zur Mitte des 14. Jahrhunderts, in alphabetical order of place names.

${ }_{48}$ Contribution of J. G. van Dillen in H. Brugmans and H. Frank, Geschiedenis der Joden in Nederland (Amsterdam, 1940); see also Bronnen tot de Geschiedenis van het Bedrijfsleven en het Gildewezen van Amsterdam, ed. by J. G. van Dillen [Rijks Geschiedkundige Publicatiën, LXIX and LXXVIII] (The Hague, 1929-33), passim. M. H. Gans, Memorboek. Platenatlas van het leven der Joden in Nederland van de middeleeuwen tot 1940 (Baarn, 1972), contains a wealth of data.

${ }^{49}$ The anti-Semitism that cannot be measured usually (see above) becomes obvious in Amsterdam in the form of sneering and, e.g., in the use of the word "smous" in the diary of Jacob Bicker Raije, a daily note of "faits divers"; F. Beijerinck and M. G. de Boer, Het dagboek van Jacob Bicker Raije, 1732-1772, naar het oorspronkelijke dagboek medegedeeld, 2nd ed. (Amsterdam, n.d.), passim. 
that no persecution would take place. It predicts that in the IJssel cities animosity would long persist. In fact, in the seventeenth century, a long time after all mediaeval links with the Jews had been broken completely, the Jews having been murdered or gone away, most of the IJssel cities did not admit them again, even though they had become as truly Protestant as Amsterdam. Only gradually, in the course of the eighteenth century, did Jews find a home in these districts. But even then a certain animosity remained, as can be seen from the fact that in 1816 , twenty years after the emancipation of all Jews in the Netherlands, the Governor of Overijssel felt compelled to take measures against unfair, discriminating competition exclusively directed against Jews. ${ }^{50}$ Eventually, modern nineteenth-century anti-Semitism could not take root even there. But in view of the above it is not just by chance that it was in Amsterdam that the February strike originated (1941) - though, of course, there were other factors too that led to the strike's starting precisely in Amsterdam.

\section{Discussion}

A number of theoretical objections can be raised against the preceding argument. The most important of these will be dealt with below.

To begin with, something should be said about the size of the interacting groups, an aspect neglected hitherto. One might say that, if the number of members of the NCPs was much larger than that of the CPs, their size, even if they were smaller in number, would have been enough to explain a hostile attitude of the population. If Jews were no longer active in agriculture and when, because of that, the non-Jewish farmers automatically became a NCP and got into a position where they would easily accept stigmatization, then, in view of the fact that the majority of the population worked in agriculture, as a matter of course the majority of the population would become a hostile mass. And even if these farmers still kept up relations with groups that had more friendly feelings towards the Jews, these groups would be unable to exert a correcting influence on that mass at all times, owing to their small size. Therefore, it seems permitted to argue that in this mass something of the primitive indoctrination would always remain present, there being insufficient indirect correction, while direct correction was entirely lacking. It is not easy to refute this argument, largely because of the intrinsic logic of the model to which it conforms. So it can only be

${ }^{50}$ Resolution of the Deputies of the States of Overijssel, August 20. 1816, "against making any difference between the members of the Jewish and the other religious communities", Provinciaal Blad van Overijssel, 1816, No 6. 
refuted by showing that some of the assumptions on which it is based or the consequences derived from them are contrary to facts.

In the first place, it must be observed that, owing to its natural dispersion, the agricultural population is not the homogeneous mass presupposed in the objection. Only very rarely does it arrive at large-scale action, and even more rarely with any success. It can be argued that the farming population, being divided into small isolated groups, because of this would be more accessible to correcting influences of small local or regional groups, the more so if these enjoyed a certain prestige; in other words that farmers never formed one, but always several CPs or NCPs. It is for this reason that housing groups were included in the model. In the second place, a farming population was rarely, if ever, able to impose its will on others. If it had been, it would not have been one of the most oppressed social groups all through the ages.

If the argument of the relatively small size of the indirectly correcting groups, the small CPs over against this large farming NCP were valid, there is no clear reason why this should not have been applicable before to the relatively even smaller directly correcting group, the Jews themselves. Even when they were still involved in agriculture they were far from omnipresent; they were a small minority of the large mass of the rural farming population. If the objection is valid, there is no reason why, because of its size, this large mass should not have come to have a hostile attitude at the time when the indoctrination started, centuries before animosity in fact began. Moreover, why was the length of the incubation period in England only one century, while in Gaul it was more than five centuries? And why was there complete resistance in Italy, where the Jews were no more numerous and so could not exert a more intense correcting influence? If we assume, however, that a theory can be fashioned which explains these differences in incubation period and which, in one way or another, revolves around directly correcting influences, or some sort of participation of Jews in agricultural life - the Council of Elvira ${ }^{51}$ comes to mind, and its prohibition of having Jews bless the harvest on the fields, which leads to the assumption of some Jewish prestige - , then the objection could still be valid. Therefore, let us assume that the large mass of the farming population was the first group that developed an antiJewish attitude and thus became the group to take the initiative, then this would lead to the conclusion that in the first phase persecutions of Jews always had to take place in the countryside.

${ }^{51}$ For the Council of Elvira see, e.g., J. R. Marcus, The Jew in the Medieval World. A Source Book, 315-1791 (New York, 1975). 
One does not need much historical knowledge to know that this statement turns out to be completely untrue. In the general image of hatred of the Jews in the Middle Ages persecutions always take place in the towns. This statement will have to be checked for the earliest persecutions, but even if it is proved true this is not sufficient to disprove the validity of the objection to the model. When the Jews were no longer active in agriculture or involved in agricultural life in one way or another, they could not but become an urban group, and inhabitants of the countryside who desired to harm them either had to ferret them out in their urban homes, or had to indulge themselves on lonely Jewish travellers in their own domain. This last was highly possible, unless the feudal lord, serving his own interest, provided sufficient protection to the Jews, and it may have occurred sometimes or even frequently. But there is not enough information available to us and it does not explain satisfactorily the clearly visible phenomenon of mass persecutions for which an explanation is sought. Moreover, it does not become clear how this form of violence is to be distinguished from a more general form of rural violence, which according to our image of those wild ages forced tradesmen to travel in large parties, and to seek the protection of castles and monasteries, in this way laying the foundations for new towns. It is not insignificant, but naturally as difficult to prove, whether the Jew was importuned for being a Jew or for being an urban outsider. From a sociological point of view the logic of the model could indeed just as well be considered applicable to non-Jewish tradesmen, the more so since these are suspect in the eyes of the clergy in much the same way. So possible rural violence does not provide either affirmation or negation of the assumptions at the basis of the model.

In the case of people from the countryside ferreting out Jews in their urban homes, a number of assumptions has to be made: 1) persecutions were demonstrably the work of farmers to begin with, 2) who travelled relatively large distances to do their bloody work, and 3) who experienced either no opposition from a - terrorized? - non-Jewish urban population, or 3 a) even acquired their - how to be explained? - active co-operation, or 4) were able to overcome this opposition. The last would be quite possible; one might think of the later Pastoureaux,,$^{52}$ and maybe of the persecutions in the valleys of the Rhine and the Danube in 1096. In general, however, this type of movement and the farmers involved came to a bad end, as in the case of the Pastoureaux. It seldom had lasting consequences.

52 About the Pastoureaux: Anchel, Les Juifs de France, op. cit., pp. 79ff.; N. Cohn. The Pursuit of the Millennium. Revolutionary Messianism in Medieval and Reformation Europe and its Bearing on Modern Totalitarian Movements, 2nd ed. (New York, 1961). 
Another construction is possible: if it can be proved that the initiators of the disastrous event of 1096 were farmers and terrorized urban poor from elsewhere who 1) were wandering about for such reasons, 2) received the active or passive co-operation of some citydwellers in the cities on the Rhine, and/or 3) terrorized these into permanent hatred of Jews, then the model is refuted, in the sense that the size of a group won over to stigmatizing could be decisive, and that for this reason no analysis of the plurality of the relations is necessary, nor mathematical analysis to explain the problem (even though all the phenomena mentioned conform to the model). Then the model would no longer be necessary, but rather an argument that there was a continuous hatred of the Jews in the cities, which had suddenly begun in 1096. In this case, of course, another theory would be required to explain the sudden character of the turn, a theory that can only use religious arguments.

Then we should return to the traditional view of the unexplained sudden "religious paroxysm" (why there and not somewhere else?) or to the politico-religious view, so brilliantly presented by Lea Dasberg. ${ }^{53} \mathrm{Her}$ book about the preliminary history of 1096 is one of the very rare ones that are based on logic as well as erudition and that aim at explaining rather than just describing. By showing the relation with the investiture struggle and thus social structures, the book presents an explanation, closely reasoned and meaningful for Germany, of the sudden character of the persecutions, but leaves aside the English and Italian problems, and to a lesser extent developments in France.

The model has not been refuted if it can be proved that the persecutions of 1096 were actually the work of people from elsewhere, of outsiders who met with resistance from most of the inhabitants of the cities concerned - resistance that was only partly successful -, or if it can be shown that the religious motivation was only an excuse. In this connection the actions mentioned above, in particular the itinerary of Peter the Hermit and Walter Sans-Avoir during the spring and early summer of the fatal year 1096, are of the greatest significance. If they were not present at the moment when the massacres began, it is possible to express doubt about the religious inspiration, about that paroxysm. The model has not been refuted if it can be proved that not only did the presupposed good relations really exist, but also that they were resumed after the storm had blown over, and remained in existence, though never quite on the old footing, up to the time when

${ }^{53}$ L. Dasberg, Untersuchungen über die Entwertung des Judenstatus im 11. Jahrhundert (Paris, The Hague, 1965). 
NCPs began to overtake CPs and thus pushed social distance over the threshold, about the middle of the twelfth century.

Another objection can be made that is rather more important: powerful groups that were not CPs themselves, but did entertain relations with such groups, could neutralize the stigma-correcting effect of the relations mentioned, or even turn them about. One could think of the nobility and the clergy in the first place. Jews could not belong to the nobility, which therefore could not be a CP. In the period before the stereotype, i.e., the period before the development of Jewish "usury", there was no particular reason for a conflict with the nobility. Moreover, in the Merovingian and Carolingian eras the nobility was not yet the clearly marked group, or series of groups, it became at a later date. It still was a group with floating boundaries.

For obvious reasons the clergy was not a $\mathrm{CP}$; moreover, it was also the source of stigmatizing. The clergy produced all the invectives and warnings against the Jews, which penetrated into the lowest layers of society. Even though a number of individual clergymen did not participate in the insinuations, and even though a number of them did entertain friendly contacts with Jews, thus weakening the impact of the group action to some extent, and even though it is true that the lower clergy was not up to its task and mostly did not understand the subtle argumentation against the Jews, or was not interested in it, still the group as such had great influence. Because its general message, its teachings, in particular the promise of final salvation, had penetrated into the hearts and minds of the entire non-Jewish population, the clergy entertained relations with all the groups mentioned above, because they brought the message. Seemingly, there is as much reason to expect $\mathrm{BZ}, \mathrm{CZ}, \mathrm{BCDZ}$ etc. relations, $\mathrm{Z}$ standing for the clergy in all its different aspects, as $A B, A B C, A B C D$ etc. relations. Seemingly, for these $\mathrm{Z}$ relations are not co-operation relations of the same type as $\mathrm{A}$ relations, but they result from the fact that each individual was concerned with religion and thus with the clergy. Does this qualitative difference suffice to undo the effect of the quantitative equality?

Using a sub-superstructure argument akin to Marxism, it could be maintained that the relations between Jews and non-Jews were more concerned with the daily world of production and consumption, with immediate material needs that were closer to people. This would even be true if the religious convictions of the large mass of the population in those so-called "gloomy" Middle Ages were much like a kind of "white magic", which was solely concerned with material desires and elementary needs. For even if in popular belief church ritual derived its sense from the fact that it enlarges the harvest and fattens the cattle, then it does so in an indirect manner, for 
prayer does not prevent people from taking all necessary measures to obtain that good harvest and to fatten the cattle. So there is little reason to assume that lay people would immediately drop the advantages of co-operation with Jews.

There is another reason why qualitative differences should undo the effect of the numerical equality of the $Z$ relations. Attending mass, performing other religious duties is no different for members of a particular professional group because they are also members of larger co-operating units. Even if the faith of the farmer differs from that of the farrier, each having different magic needs, or if faith in the countryside has a different content from that in the town - for later periods there are certainly reasons to assume that, e.g., a "proletarian" form of religious experience greatly differed from a "bourgeois" one; there are "intellectual" and "people's" churches -, it is questionable whether this made much difference before the Reformation. The clergy of a unified, really "Catholic" Church, which did not allow much initiative to lay people in the field of liturgy, which in fact treated all lay members equally, left little room for the expression of different opinions among these lay people. Debate was the field of skilled theologians. Therefore, deviations in popular belief could only find expression outside the Church, in sects or chiliastic movements. ${ }^{54}$ There is hardly any indication that such movements occurred before the turn-about in relations between Jews and non-Jews, as could be expected for the simple reason that these chiliastic movements are the result of the same social and economic developments that worsened the relations of Jews and non-Jews according to the hypothesis.

Taking it all in all, it seems justified to conclude that from the point of view of ceremonial, religious rites and spiritual leadership there was only one type of relation between the clergy and the multiform socio-economic or other groups of laymen, while there was a wide variety of relations with Jews. The relations between lay people and clergy were not strictly limited to the fields of church service and liturgy, however. The relations could be more complicated, because going to church not only has a manifest function, but also a latent one. ${ }^{55}$ Possibly more strongly in earlier times than nowadays, going to church is a social activity, in the countryside probably the most intensive one, the more so when followed by visiting the pub together. Parishioners seldom meet one another in such all-embracing faceto-face relations as on a Sunday morning. This is when, in peace and quiet,

${ }_{54}$ Cohn, The Pursuit of the Millenium, op. cit., passim.

${ }_{55}$ R. K. Merton, Social Theory and Social Structure, rev. ed. (Glencoe, Ill., 1959), pp. 9ff. 
daily cares can be discussed. Would not the intensity of this meeting under the aegis of the Church of all social groups with the exception of the Jews further stigmatizing?

The question presupposes that the latent function of the meeting, the exchange of news and opinions is less important than the manifest function; this is unlikely. Attending mass does not influence in any way the manner in which afterwards people discuss the weather, the expectations for the harvest, prices, diseases, work and its distribution, the payment of tithes or the demands of the feudal lords, etc. Only a sermon that refers to this kind of discussion may have this effect, and such a reference is difficult to imagine at a time when no secular stereotype had yet come into existence. It is only possible to insist repeatedly on the badness of the Jews in relation to daily problems of the community if a more or less accepted image of this badness exists, which has a function in explaining those problems. The idea of Jewish badness, up to then strictly theological, remained far apart from people's everyday problems and experience. Neither the ritual of the mass, be it magical or not, however important to the parishioners, nor other sacraments, however moving, did have any effect in themselves as far as indoctrination against Jews is concerned. Ritual never has this effect, with one exception, viz., the custom that the believers do not kneel on Good Friday when the prayer "Et oremus pro perfidis Judaeis" is recited. This custom, however, was only introduced after the eleventh century, i.e., at the time when the turn-about is supposed to have taken place. ${ }^{56}$

Acceptance of the need of priests' functions by the population does not necessarily mean, moreover, that as a consequence all priestly rules are conformed to. If that were so, there would be no sin. It is possible for there to be a deep contradiction between worldly and religious opinions in one person. An example from a later date may make this clear. When during the French Revolution the Constitution Civile du Clergé had been adopted, there was a clear conflict between the revolutionary ideology and the doctrine of the Church. But this did not restrain women (why women rather than men?) who had taken part in bread riots and through this had arrived at other revolutionary activities, who with their husbands accepted revolutionary aims, and showed a revolutionary fervour, from snatching unsworn priests from their hiding places and literally beating them into church and forcing them to celebrate mass. Apparently, they could not forego the magic of the ritual. ${ }^{57}$ That ideologies were contradictory was clearly not a problem. If this holds true for eighteenth-century France, after centuries of

${ }^{56}$ Anchel, Les Juifs de France, pp. 35ff.; Aronius, Regesten, No 69.

57 Address by Mrs O. Hufton at Oxford, February 1978. 
Christianity, it is even more true for early-mediaeval France, when Christianity was still young and not deeply rooted.

But could not economic dependence further the acceptance of stigmatization? Indeed, relations between laymen and clergymen were not restricted to the purely transcendental aspects of human life, but sometimes in fact were directed towards worldly matters, production and consumption. Serfs working the lands of the abbeys, free peasants who had to pay tithes, artisans taking part in the building of churches, hospitals, monasteries, etc., all had their particular group relations with groups of clergymen. But this does not mean that having these relations more often led to accepting a stigma that was essentially theological than not having these relations did. Were the serfs or semi-free peasants of San Giulia or Saint Germain, or the many other abbeys, forced to share the opinions of their regular clergy by their dependence of them, or did the fact of their exploitation, their hard work for low wages, make them rebellious and, for this reason, the less inclined to share the views of their masters? It is unlikely that peasant Bodo, who belonged to the abbey of Saint Germain, thought in these terms, but he must have had his moments of bitterness, of falling back on pagan practices, his belief in old rituals and magic potions, which he was forced against his will to confess. His way of celebrating the Christian festivals, drinking, dancing and singing bawdy heathen songs, suggests that he did not care very much for the opinions of his masters, the monks. Even though there was a saying that it was "good to live under the crook", profanity and exploitation together did not induce Bodo and his fellow-victims to blind obedience, ${ }^{58}$ so did not necessarily lead to an easy acceptance of anti-Jewish indoctrination. Moreover, as the purely social relations with the clergy were restricted to a few groups, there is no reason to assume that all CPs of Jewish subgroups had such contacts.

Finally, it must be noted that the clergymen who were capable in looking after material interests of their own group, the able administrators, probably were among the more worldly-minded members of the group. There may have been exceptions, such as Suger of Saint Denis, who was both a scholar and a capable administrator, ${ }^{59}$ but generally speaking most men of this type will have been less accomplished in theological speculation and scholarship, less inclined to study the subtleties of doctrine, and thus less probable instruments for anti-Jewish indoctrination. In summary, it can be said that both from a quantitive and from a qualitative point of view the

${ }^{58}$ E. Power, "The Peasant Bodo", in Medieval People (Harmondsworth, 1954), pp. $11 \mathrm{ff}$.

${ }^{59}$ Pounds, An Economic History, pp. 96, 109, 132, 168. 
interactions with the clergy were not strong enough to undo the stigmacorrecting influence of the relations with Jews. A presupposed relatively sudden decrease of these relations between Jews and non-Jews thus gains significance as an explanatory variable, the more so because of the sudden character of the turn-about.

As to the significance of the threshold value the objection might be made that, according to the method of calculation used, in the Rhineland, where the bloody persecutions of the First Crusade took place in 1096, social distance must have been below the threshold value. In other terms, F was greater than SD. This implies that either the model is wrong, or the persecutions were committed by passing outsiders without the co-operation, or even with the active opposition, of the inhabitants. From the literature quoted it is clear that this was the case..$^{60}$ So the model has not been refuted.

\section{The persistence of the stereotype}

Now that a possible explanation has been given for the rise of an anti-Jewish stereotype in the decrease of open opportunities for interaction between Jewish and non-Jewish groups, the question can be asked whether the process is reversible. It can be argued that this is impossible, or at least extremely difficult, firstly, because the pattern of interaction from then on has the character of labelled interaction. This can be elucidated by the Jewish example. Once the stereotype has been fashioned, the Jewish group as such has been reduced to one, externally homogeneous, subgroup of society as a whole, which always consists of the same members, irrespective of the question whether the aspect from which the group is looked at is of a social, economic, religious, legal, geographical or even a linguistic nature in other words, precisely the discriminatory situation described by Lewin, ${ }^{61}$ in the sense of a situation in which one member of a certain group that is the subject of discrimination behaves, or feels compelled to behave, as a member of that group in every imaginable situation (the Jewish doctor who in consultancy with other doctors does not primarily behave as a doctor, but as a Jew).

Such a reduction does not at all mean that there are no longer any differences between Jews, that Jews are one another's equals in every respect. On the contrary, there is bound to be enough internal differentiation to render this impossible. Within the Jewish group there will continue

60 See note 28.

61 B. K. Lewin, Resolving Social Conflicts. Selected Papers on Group Dynamics (New York, 1948). 
to be artisans who work for the Jewish market, such as kosher butchers, Torah writers or tailors; as before, there will be all those who as clerks or servants depend on the wealthier Jews, as well as all the characters of a rich Jewish folklore ${ }^{62}$ there will be revered Talmud students, rabbis, judges, etc. Reduction to one social category does not mean that the Jewish communities with their separate existence in ghettos etc. would not present the characteristics of a human society as differentiated as any other. This reduction only implies that from the point of view of the overwhelming majority of non-Jewish society the Jews - the generic term is no chance occurrence - are considered as one homogeneous group in an unfavourable sense, feared and despised, and as such dehumanized, a group concentrated on doing evil, without any exception. In other words, the members of an outgroup are always seen as exactly the same ${ }^{63}$ (when discriminating against Chinese the discriminator thinks all Chinese look alike).

Distinctions between Jews became vague in the perception of non-Jews, because to them they only had one function in non-Jewish society, viz., that of the disbelieving furnishers of dirty money, and the unproductive exploiters of human labour, who practised strange customs and lived by their unintelligible law in their weird, inaccessible, separate districts of the town, and who might be far from harmless if Christian princes did not restrict them. Possibly, the majority was unconscious of this legal characteristic, which can be classed as Jewry-law as distinct from Jewish law, a distinction first formulated by Kisch. ${ }^{64}$ The latter is the legal system that, autonomously, legislated for the relations between Jews, based on the traditional Jewish law and commentaries, as those of the Geonim, ${ }^{65}$ adapting Jewish law to life in non-Jewish surroundings. The former is the conglomerate of rules that determine the relations between Jews and non-Jews, rules concerning trade in money and securities, punishment of transgressions, taking the oath more judaico, etc. Both the legal rules and the less formalized constituent social standards for the relations between Jews and non-Jews took the form of so-called labelled interaction.

This is the interaction in a discriminatory situation. It can be defined as a way of observing the other group that is standardized by categorizing and generalizing, which allows the members of that group only a limited number of actions, all true to type, and which always makes these actions into

62 A Treasury of Jewish Folklore, ed. by N. Ausubel (New York, 1980).

${ }^{63}$ Allport, The Nature of Prejudice, op. cit., pp. 166ff.

o4 G. Kisch, The Jews in Medieval Germany. A Study of Their Legal and Social Status (Chicago, 1949).

${ }_{65}$ See, e.g., M. Wurmbrand and C. Roth, The Jewish People. 4000 Years of Survival (London, 1966), pp. 104ff. 
self-fulfilling prophecies. The dominating group, owing to its position of power, imposes its ideas about the subjected group on that group as a label, in forcing it to behave according to the label. Dominating and subjected groups never meet in other ways than those contained in the label. Such patterns of meeting, once determined, become fixed as long as the labelling group is on top, and such patterns are necessarily confirming and continuing prejudices. The behaviour of the dominating group, led and above all limited by the label, compels the subjected one to a reaction that is determined and limited by the label. The larger the dominating group, the larger the internal system of terrorizing, confirming the system, and the smaller the opportunities for individual members of the dominating group to sin against its standards, by behaving in a humane manner towards members of the subjected group. Fortunately, there have always been such "sinners" (see below), as, to quote one example, the washer woman who saved the life of a Jewess during the persecutions of Würzburg of 1147, against the wishes of a furious mob. ${ }^{66}$

The expectation and the forced obedience to this expectation makes the black play "Sambo", the irresponsible, joyful, child!ike, lazy "nigger". This too is an example of "labelled interaction", just as the imposed role of the black nanny to whom white children are entrusted when they are small, whereas they are no longer allowed to sit next to the same nanny in a bus or train when they are grown up. Thus the role of the black labourer who, excluded from skilled labour by trade unions and employers, in this way not only "proves" that he is suited only for unskilled work, but is also forced to accept this argument as valid, or at least to appear to do so.

In the present case, labelled interaction is considered to be only that interaction that lies within the margins of a re-interpretation of Jewish action that is coloured by a theological stigma, but added to by popular beliefs, and which, in a way that is dictated by the methods described, forces Jews into behaviour that confirms the label and admits of its expansion and enlarging. So the label that is continually provided with new negative characteristics forced the Jew into a mode of behaviour that conforms to these, and is more and more restricted. The label could be attached, because there was no longer a stigma-correcting co-operation at that time. Once this condition was fulfilled, the label will have been attached the more readily the more the prestige of the authorities that formulated the system of beliefs rendered the former non-acceptance of the stigma painful. When the pain of the contradiction in the system of belief was no longer counteracted by the pain of the contradiction between stigma

os Neubauer and Stern, Hebräische Berichte. 
and experience, it was reasonable to hasten to accept the stigma. The deductive inference became negative, the prejudice reinforced itself, and the whole process most probably became irreversible.

The question may be asked whether and, if so, why such a situation acts in a self-confirming way, and why it cannot be undone or, if so, only with great difficulty. When considering comparable groups, untouchables in India or Japan, blacks in the United States or South Africa, it is striking that the victim always has a fixed place and a specific role within the suppressing society. The minority performs tasks that the majority is not willing or unable to perform, but cannot do without. Work abominated by whites, despised as Kafir work and performed by blacks, is essential for the South African economy. The Indian or Japanese societies can no more dispense with the dirty jobs of the untouchables, in Japan the Eta, ${ }^{67}$ despised by the majority, such as scavenging and removing the carcasses of animals. It is inessential whether the label was attached to the members of the groups because they were doing despised work, or whether the tasks were given them because they were despised people. The task justifies the label and vice versa. This double conception in effect channels the minimum of interaction between majority and minority: just as much is permitted as is necessary for the set task to be performed. The task itself is defined by the idea the majority has of the minority: dirty people do dirty jobs. It is labelled interaction indeed.

In the case of mediaeval Jews it could be said that, after the disappearance of other forms of - open-interaction, the form of labelled interactions was limited, in a way prescribed by circumstances, to seeing to it that Jews in the end only carried out the practice of usury, indispensible but despised and abhorred and condemned by the Church, which was rewarding exclusively to princes, for they received the ultimate results. It was a task by which the murderers of Christ, who had sold the Messiah for thirty pieces of silver (in anti-Semitic folklore Judas and Judaism are often identified), could further soil their already unclean hands.

Such simplifying and generalizing (usually unfavourable) judgments of other nations are not limited to the above circumstances. They occur frequently in the (historical) literature about the non-European world. ${ }^{68} \mathrm{~A}$ characteristic of these stereotypes is, however, that they can be changed, in the sense that many a (negative or positive) stereotype may sometimes be changed for another, and because of that does not lead to labelled interac-

${ }^{67}$ N. Passin, "Untouchability in the Far East", in: Monumenta Nipponica (Tokyo), XI (1955), pp. 27ff.

${ }_{68}^{6}$ R. Preiswerk and D. Perrot, Ethnocentrisme et Histoire. L'Afrique, l'Amérique indienne et l'Asie dans les manuels occidentaux (Paris, 1975). 
tion. These changes can be brought about by changes in the circumstances of the observer group. West European judgments of, e.g., the Hungarians, in their extreme simplification clearly stereotypes of a mostly negative character, have been subject to considerable changes. Originally regarded as robbers and murderers, in the sixteenth century the Hungarians became heroes struggling against the "unspeakable Turk", and their military organization was imitated with great admiration - as proved by the word hussar, taken over in all European languages. Thus they became the romantic cavaliers of the puszta, for whom the enlightened philosophes, who saw them as barbarians, felt very little sympathy, however. One can go on like this and discover that in the nineteenth and twentieth centuries in the eyes of the West Europeans the Hungarians changed from ideal Liberals into oppressors of Slavs and Fascists that admired Hitler, to end as noble antiCommunists or, in the eyes of somebody else, as ideal Communists. It is the way of observing that changes rather than the Hungarians, and it is the changes in the circumstances of the observers that brings this about. ${ }^{69}$

This changeability, one might suppose, is only possible because these distant nations do not live within one's own society, do not have a specific task to do for the observers, who therefore have no reason to associate with them in a particular way. In other words, the circumstances themselves that lie at the basis of labelled interaction explain its almost unchangeable character. Changes could only be brought about by making Jews once again into an integrated part of the non-Jewish society, which happened during the Emancipation, be it imperfectly. ${ }^{70}$

The unchangeability of social position and image making may have had other consequences. Just because it was so difficult to make a change in the system of relations, or rather the absence of relations, there is room for what Barrington Moore so strikingly called the "moral authority of suffering and injustice". ${ }^{71}$ Moore founds his considerations not only on the selfinflicted suffering of ascetes, or the suffering of the untouchables imposed from above, but, very characteristically, upon various analyses of Nazi concentration camps, studies dealing both with the way in which the oppressors saw their victims, and with the reactions of the victims. His

69 A. N. J. den Hollander, Visie en Verwoording. Sociologische essays over het eigene en het andere (Assen, 1968), pp. 7ff.

30 An extremely fascinating discussion about the imperfect character of the emancipation of the Jews: J. Katz, Out of the Ghetto. The Social Background of Jewish Emancipation 1770-1870 (Cambridge, Mass., 1973); and R. Rürup, Emanzipation und Antisemitismus (Göttingen, 1975).

71 B. Moore, Jr, Injustice. The Social Bases of Obedience and Revolt (White Plains, N.Y., 1978), ch. II. 
attention is directed chiefly to the bewildering question why people so often accept suffering and oppression, even adapt to them positively, and just as often or more often rebel against them. What decides this choice? As to the former, he argues very convincingly, the point is that people adapt by making the suffering part of an internalized moral code, and thus make adaptation into a form of moral self-exaltation. In Moore's argument this attitude will dominate when the victims have the feeling that they do not have the means at their disposal to change the situation.

Thus it might be argued that, after isolation had started in the manner described, resulting in a system of stigmatizing and stereotyping that confirmed and enlarged itself, and in its turn was stimulated by terrorizing, thus leading to complete oppression, the victims who saw no way out and, as a minority, lacked the means of opposition, had no other choice but to give a moral meaning to their oppression. This would be the easier if the culture of the oppressed knew a tradition of interpreting suffering as a form of penance for sins committed. It would be even easier if the culture of the oppressors also knew such an interpretation of penance. In the case under consideration this is indeed true for both groups. Both Christians and Jews could, each in their own way, interpret and rationalize the need for oppression as a moral adaptation to an order willed by God. The victims could, and most probably did, have the feeling that by preferring martyrdom to saving one's life they honoured God's name. The many stories about the mass suicides by Jews, or descriptions of how Jews let themselves be slaughtered without resistance rather than be baptized, during the Crusades, during the persecution of York in $1190,{ }^{72}$ during the Black Death, etc., strongly suggest this.

Such an attitude largely explains the completely rigid character of the mediaeval relations between Jews and non-Jews, and also the later negative character and infrequency of such relations, the inevitability of it. The "moral authority of suffering and injustice" indeed provides a good explanation of the fact that in spite of the ever increasing oppression, the more violent persecutions, Jews did not give in and preferred to suffer the insufferable, and thus encouraged the fixed idea of the malicious, obstinate Jew, which served to justify the oppression.

One other point requires attention. It might be said that after a change of circumstances, after (new) crafts as, e.g., the printing trade had once again been opened to Jews, new types of co-operation could come into existence, which could undo the prejudice that had been fashioned, in the same way as it had come into being. This is unlikely as a rule. After all, social distance is

72 Dobson, The Jews of Medieval York, op. cit. 
considered a necessary condition, but not a necessary and sufficient condition. Therefore, if the other necessary conditions were also present, such as stigmatizing and terrorizing of the discriminator, it is not clear how new patterns of interaction, the removal of isolation alone, could undo the prejudice. In a situation of prejudice, following the same trade does not necessarily mean co-operating.

Tailors educated in anti-Semitism will not drop their anti-Jewish feelings at the discovery that there are Jewish tailors, be they competitors or not. Jewish typographers, who often printed Hebrew texts, were engaged in the printing trade in a rather different way from non-Jewish typographers, even though it is true that in the Netherlands, a centre of Hebrew-printing shops of old, Jewish typographers, as well as Jewish diamond workers, could play an important part in the general trade-union movement; but this was typically a situation in which anti-Semitism according to the model had hardly been developed. It is questionable whether a similar co-operation could as easily have arisen in Poland or Germany. Moreover, even if Jewish and non-Jewish workers in new industries or industrial organizations co-operated and trusted each other, such a situation is often no more than partially healing. It does not touch anti-Semitic farmers. It is known that people who have grown up in an anti-Semitic situation and who get into a situation where they attain some forms of co-operation with Jews change their opinions towards these Jews, but not necessarily towards the Jews as such. Early Socialism, in particular in France, but also in other countries, and not only that of the Utopians, ${ }^{73}$ was sensitive to anti-Semitic agitation, precisely because solidarity with the Jewish proletarian did not always counterbalance the hatred of the Jewish capitalist. There was a tendency to hate them as Jews, strengthened by a mistaken interpretation of Marx's Zur Judenfrage, until the leaders like, e.g., Bebel taught the comrades differently. ${ }^{74}$

The Jews one did meet were seen rather as the exceptions that confirm the rule. Unfortunately, increased interaction did not lead to a changed view of the Jew as an abstraction. It reminds one of the sinister joke that was told in Nazi Germany: "There is no anti-Semitism in Germany, for every German has a Jewish friend", to which Heinrich Himmler referred when he addressed the SS Generals at Posen on 4 October 1943: "The Jewish race is being exterminated', says a Party member. 'That's quite clear, it's in our programme - elimination of the Jews - and we're doing it,

73 See Pt II of my book; for a survey my "Racism in Europe", loc. cit.

74 A. Bebel, Sozialdemokratie und Antisemitismus. Rede auf dem Sozialdemokratischen Parteitage in Berlin [sic]. Mit zwei Nachträgen, 2nd ed. (Berlin, 1906). 
exterminating them.' And then they come, 80 million worthy Germans, and each one has his 'decent' Jew. Of course the others are vermin, but this one is a first-rate Jew." 75 Those eighty million Germans were only too ready to leave Himmler and his henchmen a free hand to deal with "the others" as he thought fit. There are exceptions to this rule (even in Nazi Germany, where private persons sometimes kept Jews in hiding for years, even in the centre of Berlin, at enormous personal risks ${ }^{76}$ ), but they are the rarer the stronger the risks by accepting stigmatizing and terrorizing. That risk is greater when the authority that has the monopoly of violence is itself terrorizing, as in Nazi Germany, or maybe to a lesser degree in Tsarist Russia or South Africa. It is great when public opinion terrorizes by means of social control as, e.g., in the South of the United States, and when opposing vested public opinion is dangerous, because private violence is condoned or cannot be prevented. For these reasons the effect of increasing interaction is only small, and thus the process is irreversible.

It is to be hoped that prejudice can be overcome, but, unfortunately, not by a change in the pattern of interactions, however important this is. As Greenberg has shown for other situations, ${ }^{77}$ to attain this a complete change of the social and economic structure of a traditionally discriminating region is necessary. Not until agriculture in Alabama had been completely mechanized and a reservoir of cheap labour, maintained by discrimination and prejudice, was no longer needed, not until the big employers came to see that discrimination was no longer profitable, and not until the trade unions began to see the advantages of desegregation, could an increasingly open interaction begin its salutary work.

\section{Implications for policies}

The irreversibility of the process, however, is not an argument against the validity of the analysis presented above, but it is a strong warning for whoever can and will read it, provided it is right. When a process of growing prejudice is just beginning, when the stereotype has not yet become fixed, has not yet been anchored in an intolerant public opinion, open interaction could be a useful means of prevention. For if one thing is clear from the model, if it is valid, it is this that being without prejudice, contrary to being

75 Documents on Nazism, 1919-1945, ed. by J. Noakes and G. Pridham (London, 1974), p. 492.

${ }_{76}$ E. Boehm, We Survived. The Stories of Fourteen of the Hidden and Hunted of Nazi Germany (New Haven, 1949).

${ }_{77}$ S. B. Greenberg, Race and State in Capitalist Development. Comparative Perspectives (New Haven, London, 1980). 
prejudiced, as a result of maximum interaction is definitely dependent on numbers.

The basic idea of American school integration, bringing together children who have not yet been indoctrinated, is far from ridiculous, seen from this point of view. That the scheme failed was because its execution was not good. Given the existing system of paying for the schools school integration caused the quality of education to deteriorate for the average white child. In principle, such effects can be repaired. They should never be a reason to reject a policy that is aimed at maximum open interaction.

Translated from the Dutch by M. W. H. Schreuder 